\title{
STUDIES OF THE DIPYRRYLMETHENE ("FUSCIN") PIGMENTS. III. THE VARIABLE FATE OF BILIRUBIN DEPENDING UPON CONJUGATION AND OTHER FACTORS *
}

\author{
By A. SIGRID GILBERTSEN AND C. J. WATSON
}

(From the Department of Medicine, University of Minnesota Hospitals, Minneapolis, Minn.)

(Submitted for publication April 28, 1961 ; accepted August 4, 1961)

It has been well established that bilirubin excreted in the bile is normally converted to the urobilinogen group in the colon through a series of reductions by the bacterial flora. This subject has been reviewed in recent papers (1-3) and need not be considered in detail here. Maly $(4,5)$ first suggested the enterogenous (bacterial) formation of urobilin and this was first demonstrated in 1893 in the classic study of von Müller (6) who fed urobilin-free swine bile by tube to an individual having complete biliary obstruction and subsequently recovered urobilin from the feces and urine. However, later attempts to demonstrate urobilinogen formation after tube-feeding of solutions of crystalline bilirubin were generally disappointing; the amount of bilirubin converted to urobilinogen in these studies was 10 per cent or less (7-10). It has also been apparent that measurement of urobilinogen excretion does not consistently reflect the rate of hemoglobin catabolism and that discrepancies of considerable magnitude are at times noted $(1,2)$.

It has been suggested that the failure to recover urobilinogen after tube-feeding of crystalline bilirubin might be due to conversion of the bilirubin to dipyrrylmethenes such as mesobilifuscin and, similarly, that discrepancies between urobilinogen excretion and hemoglobin destruction might be reconciled by measurement of mesobilifuscin excretion (11-13). These concepts, however, were not supported by recent studies $(14,15)$ which indicated that at least the majority of the naturally occurring fecal dipyrrylmethene or mesobilifuscin is anabolic in origin and reflects pyrrol synthesis on the pathway toward heme, rather than hemoglobin destruction. Nevertheless,

* Aided under a contract with the Research and Development Command, Office of the Surgeon General, United States Army, and by a grant from the Medical Research Fund of the Graduate School, University of Minnesota. it is recognized that bilifuscin or mesobilifuscin may be derived by oxidation of bilirubinoid compounds under appropriate conditions and that a fraction of it may originate in this way. This will be considered again below.

Another possible explanation for the failure to demonstrate conversion to urobilinogen of tubefed crystalline bilirubin presented itself with the knowledge advanced by Billing and Lathe (16) and by Schmid, Hammaker and Axelrod (17, 18) that at least the major fraction of the prompt direct-reacting (polar) bilirubin of the bile is conjugated with glucuronic acid in contrast to the indirect-reacting free (nonpolar) bilirubin. Subsequently, it could in fact be shown that the conjugate is somewhat more efficiently reduced by the fecal flora in broth cultures, in vitro, than is free bilirubin (19). Whether this is owing to the more polar character of the conjugate, or conversely, whether the free bilirubin actually tends to inhibit bacterial activity, as suggested by Baumgärtel (20), is unknown.

The present study was undertaken to clarify the significance of mesobilifuscin in situations where discrepancies between calculated and measured bile pigment excretion exist and to determine the significance of conjugation of bilirubin for its reduction by the fecal flora. For these purposes a comparative study was made of the recovery of urobilinogen and mesobilifuscin after tube-feeding crystalline bilirubin, bile, and bilirubin glucuronide and after intravenous administration of crystalline bilirubin, in normal subjects and in patients with biliary obstruction.

In the course of this investigation an unusual case of chronic anemia was studied in which there was a large discrepancy between the measured rate of hemoglobin destruction and the fecal urobilinogen excretion. Brief mention of this patient has been made in an earlier paper (2). Ex- 
tensive studies were carried out in an attempt to determine whether measurement of mesobilifuscin would reconcile the discrepancy, determine the fate of bilirubin in this patient, and illuminate the relationship of the demonstrated abnormal pigment metabolism to the clinically refractory anemia. Results of these studies are included in the present report.

\section{MATERIALS AND METHODS}

A. Intubation studies. Nine subjects were fed either bilirubin or bile intraduodenally. Crystalline $\mathrm{N}^{15}$-labeled bilirubin was administered to three patients with biliary obstruction, to one patient who had recently undergone cholecystectomy and choledochotomy and had a T-tube in place, and to one normal 38 year old male subject. $\mathrm{Hu}$ man bile of known bilirubin concentration was administered to one patient with biliary obstruction. A relatively crude preparation of bilirubin glucuronide (see below) was given to one normal 29 year old male subject and to two patients with biliary obstruction. All of the patients with biliary obstruction had carcinoma of the head of the pancreas and the degree of obstruction was high grade or complete in each instance. Intraduodenal feeding was accomplished through a $\mathrm{T}$-tube in the common bile duct in one patient and by intubation of the duodenum with a Camus tube in all others. Carmine, $0.32 \mathrm{~g}$, was added to each feeding to serve as a marker.

The crystalline $\mathrm{N}^{15}$-bilirubin contained 1.652 atom per cent excess $\mathrm{N}^{15}$ and had previously been isolated from the feces of patients with hemolytic anemia after feeding of $\mathrm{N}^{15}$-glycine and antibiotics (21). In four experiments either 200 or $300 \mathrm{mg}$ of crystalline $\mathrm{N}^{15}$-bilirubin was dissolved in $0.05 \mathrm{M} \mathrm{Na}_{2} \mathrm{CO}_{3}$. In the fifth subject $300 \mathrm{mg}$ of crystalline $\mathrm{N}^{15}$-bilirubin was given as a very fine suspension in $50 \mathrm{ml}$ of a previously prepared 2 per cent crude bile salt solution. The latter contained $1.0 \mathrm{~g}$ of "sodium glycocholate" (Mallinckrodt) in $35 \mathrm{ml}$ of distilled water, filtered through a medium sintered glass funnel, the solution then being made up to $50 \mathrm{ml}$ with distilled water.

The human bile was obtained from a patient who had recently undergone cholecystectomy and had a $\mathrm{T}$-tube in the common bile duct; collection was made in a sterile container and culture failed to yield pathogenic bacteria. It was kept frozen until used; $0.32 \mathrm{~g}$ carmine was added to $470 \mathrm{ml}$ of the freshly thawed bile which contained 188 mg bilirubin.

The relatively crude preparation of bilirubin glucuronide was prepared from fresh human bile obtained by T-tube drainage. The method used for preparation of an adsorbate on Hyflo has been previously described (19). This material was kept in the deep freeze until needed. The bilirubin glucuronide was then eluted from the Hyflo by phosphate buffer, $\mathrm{pH}$ 6.8. The crude material represented in this solution includes small amounts of bile salts, $4.7 \mathrm{mg}$ per $\mathrm{g}$ of powder, by the method of Carey (22).
Collection of feces was commenced 4 days before the duodenal feeding and continued for 4 days after excretion of the carmine-marked administered materials. Urobilinogen was determined by the method of Schwartz, Sborov and Watson (23), and mesobilifuscin (Mbf) by the modification of Siedel's method previously reported $(14,15)$. In contrast to earlier procedures yielding a crude material of lower nitrogen percentage, this method has regularly provided material of a nitrogen content in agreement with theory (11). Furthermore, it was previously shown that strenuous oxidation of the fecal Mbf obtained by this method gave amounts of methyl ethyl maleimide in good agreement with theory. Bilirubin was determined by the method of Malloy and Evelyn (24), adapted to feces. When crystalline $\mathrm{N}^{15}$-bilirubin was given, stercobilin and $\mathrm{Mbf}$ were isolated from the feces according to methods previously described $(14,25)$. In three of these patients, 48-hour urine collections were made after administration of crystalline $\mathrm{N}^{15}$-bilirubin, and bilirubin was isolated from the urine $(21)$. The $\mathrm{N}^{15}$ percentages were determined in the mass spectrometer after preliminary digestion, according to Rittenberg (26). ${ }^{1}$

$B$. Intravenous administration of crystalline bilirubin. A normal woman, aged 28, was given crystalline bilirubin (Armour) intravenously on 8 successive days. Each day the bilirubin to be infused was dissolved in 20 to $30 \mathrm{ml}$ of hot $0.1 \mathrm{M} \mathrm{Na}_{2} \mathrm{CO}_{3}$ and added to a physiological saline infusion. It was administered slowly over a period of 45 to 60 minutes. The amount per day was gradually increased; beginning with $1.0 \mathrm{mg}$ per $\mathrm{kg}$, a total of $1,082 \mathrm{mg}$ was given over the 8 -day period (Table IV). Collection of feces was made for 16 days beginning 4 days before the intravenous administration of bilirubin. Each 4-day collection was pooled and thoroughly mixed, and analyses for urobilinogen, Mbf, and bilirubin were then made by the described methods.

C. Studies in a patient with refractory anemia. A.B., female, 36, married, the unusual patient with refractory anemia mentioned above, had had a known chronic anemia unimproved by the usual methods of treatment, except occasional transfusions, since 1952. Iron and vitamin $B_{12}$ had been administered repeatedly without effect. She had received no therapy and no transfusions since 1956 with the exception of a 1-month trial of cobaltous chloride in 1957, which failed to elicit any response in hemoglobin or reticulocyte values. There were no abnormal physical findings. The anemia was normochromic and normocytic; hemoglobin determinations averaged 10 g per $100 \mathrm{ml}$ without therapy. Over a 7 -year period the eythrocyte count ranged from 2.58 to 3.69 million per $\mathrm{mm}^{3}$, the hematocrit 28 to 36 per cent, the leukocyte count 3,700 to 8,650 per $\mathrm{mm}^{3}$. The differential count was normal. Reticulocyte counts ranged from 0.4 to 2.8 per cent with the majority of values in the range of 1 per cent. Bone marrow biopsies revealed normal total cellularity but normoblastic hypoplasia (normoblasts comprised

${ }^{1}$ Carried out in the Department of Physics, University of Minnesota, through the courtesy of Professor A. O. Nier. 
TABLE I

Conversion to urobilinogen and mesobilifuscin of crystalline bilirubin given by duodenal intubation and $T$-tube

\begin{tabular}{|c|c|c|c|c|c|c|}
\hline $\begin{array}{l}\text { Subject } \\
\text { no. }\end{array}$ & Condition & Year & $\begin{array}{l}\text { Cryst. } \\
\text { bilirubin }\end{array}$ & $\begin{array}{l}\text { Conversion } \\
\text { to fecal } \\
\text { urobil. }\end{array}$ & $\begin{array}{l}\text { Conversion } \\
\text { to fecal } \mathbf{M b f}\end{array}$ & $\begin{array}{l}\text { N15_bilirubin } \\
\text { in urine }\end{array}$ \\
\hline & & & $m g$ & $\%$ & $\%$ & $\%$ \\
\hline 1 & Biliary obstr. & 1934 & 275 & 8.8 & Not done & \\
\hline 2 & Biliary obstr. & 1934 & 300 & 10.5 & Not done & \\
\hline 3 & Biliary obstr. & 1955 & $200^{*}$ & 0.0 & 0.0 & Not done \\
\hline 4 & Biliary obstr. & 1955 & $200^{*}$ & 0.0 & 0.0 & 0.38 \\
\hline 5 & Normal subject & 1955 & $300^{*}$ & 5.0 & 0.12 & 0.0 \\
\hline 6 & $\begin{array}{l}\text { Postop. cholecyst- } \\
\text { ect. T-tube }\end{array}$ & 1955 & $200^{*}$ & 15.7 & 0.44 & 0.0 \\
\hline 7 & Biliary obstr. & 1955 & $300 * t$ & 16.9 & 0.56 & Not done \\
\hline
\end{tabular}

* Labeled with $\mathrm{N}^{15}$

$\dagger$ In $2 \%$ crude bile salt solution.

only 9.7 per cent of the nucleated marrow cells). Decreased iron stores in the marrow had been noted since 1959. Studies in 1960 documented the recent development of frank iron deficiency in addition to normoblastic hypoplasia. As noted above, previous therapy with oral iron preparations had repeatedly failed to correct the anemia. Using the method of Read (27) for measurement of red cell survival with $\mathrm{Cr}^{51}$, the $\mathrm{t}_{\frac{1}{2}}$ was 27.5 days (normal in this laboratory is 25 to 30 days), and the calculated circulating hemoglobin was $380 \mathrm{~g}$. Thus, a normal red cell life span of 120 days and normal hemoglobin catabolism assumed, the anticipated daily excretion of fecal urobilinogen would be $133 \mathrm{mg}$. In reality, however, the measured urobilinogen excretion over several periods of observation averaged but $30 \mathrm{mg}$ daily. This patient's history recorded no broad spectrum antibiotics. The discrepancy was in no way accounted for by excretion of $\mathrm{Mbf}$, which averaged only $6.5 \mathrm{mg}$ daily.

If the urobilinogen excretion accurately reflected hemoglobin catabolism, the red cell life span in this patient at the time of these measurements would have been 469 days, a most unlikely duration. In an effort to explain this marked discrepancy and to shed light on the fate of bilirubin in this patient, the following studies were made. Crystalline bilirubin was given intravenously in increasing doses, with a total of $1,056 \mathrm{mg}$ administered over an 8-day period in the same manner as that described for our normal subject. Collection of feces was made for 16 days, beginning 4 days before bilirubin administration. In a study 2 months later, a carminemarked solution containing $198 \mathrm{mg}$ of bilirubin glucuronide was administered intraduodenally, and feces were then collected over the next 6 days. On another occasion $147.5 \mathrm{mg}$ of crystalline mesobilirubinogen, obtained after amalgam reduction of crystalline bilirubin (28) and crystallized from petroleum ether, was given via duodenal tube. The feces were collected for 11 days, beginning 4 days before intubation. All fecal specimens were analyzed for urobilinogen, Mbf, and bilirubin by the described methods. To investigate the nature of the patient's intestinal bilirubin, a Miller-Abbott tube was passed to the level of the upper jejunum and steadily advanced over the next 4 hours to the ileum. Aspiration specimens were obtained every 30 minutes and the amounts of 1 -minute prompt direct-reacting bilirubin and total bilirubin were determined on each sample $(29,30)$.

\section{RESULTS}

In accordance with studies already cited, the recovery of tube-fed crystalline bilirubin as fecal urobilinogen was meager. No evidence was obtained to support the suggestion that this poor recovery was owing to a principal conversion of bilirubin to mesobilifuscin. The conversion to $\mathrm{N}^{15}$-labeled urobilinogen and mesobilifuscin and the amount of $\mathrm{N}^{15}$-bilirubin appearing in the urine after intraduodenal administration of crystalline $\mathrm{N}^{15}$-bilirubin to five subjects are shown in Table I. Also included in Table I are the results of the older but similar study of 1934 . The conversion of bilirubin to urobilinogen was 10 per cent or less in all subjects ( 1 to 6 ) given bilirubin dissolved in $0.05 \mathrm{M} \mathrm{Na}_{2} \mathrm{CO}_{3}$; in two of these subjects ( 3 and 4) no labeled urobilinogen could be demonstrated.

TABLE II

Human bile by duodenal intubation in biliary obstruction *

\begin{tabular}{lccc}
\hline \hline & $\begin{array}{c}\text { Fecal } \\
\text { urobil. }\end{array}$ & $\begin{array}{c}\text { Fecal } \\
\text { Mbf }\end{array}$ & $\begin{array}{c}\text { Fecal } \\
\text { bilirubin }\end{array}$ \\
\hline $\begin{array}{c}\text { Average per diem excretion pre- and post- } \\
\text { bile, } m g\end{array}$ & 7.0 & 0.0 & 1.1 \\
$\begin{array}{c}\text { Average per diem excretion carmine-marked } \\
\text { specimens over 6-day period, } m g\end{array}$ & 13.2 & 0.2 & 3.2 \\
$\begin{array}{c}\text { Total excess of bilirubin or derivatives in } \\
\text { carmine-marked specimens over 6-day } \\
\text { period, } m g\end{array}$ & 37.2 & 1.2 & 12.6 \\
$\begin{array}{c}\text { Conversion or excretion of administered } \\
\text { bile bilirubin, \% }\end{array}$ & 19.7 & 0.6 & 6.6 \\
$\quad$ Total recovery $51.0 \mathrm{mg}$ or $26.9 \%$ & & \\
\hline
\end{tabular}

* $470 \mathrm{ml}$ bile containing $188 \mathrm{mg}$ bilirubin. 
TABLE III

Conversion to urobilinogen and mesobilifuscin of bilirubin glucuronide $(B-G)$ given by duodenal intubation to three subjects

\begin{tabular}{|c|c|c|c|}
\hline & $\begin{array}{l}\text { Normal subject, } \\
294 \mathrm{mg} \mathrm{B-G}\end{array}$ & $\begin{array}{l}\text { Biliary obstr. } \\
50 \mathrm{mg} \mathrm{B}-\mathrm{G}\end{array}$ & $\begin{array}{l}\text { Biliary obstr. } \\
182 \mathrm{mg} \mathrm{B}-\mathrm{G}\end{array}$ \\
\hline \multicolumn{4}{|l|}{ Urobilinogen, $m g / d a y$} \\
\hline $\begin{array}{l}\text { Average pre- and post-B-G } \\
\text { Carmine-marked samples }\end{array}$ & $\begin{array}{r}92.5 \\
233.0 \text { ( } 2 \text { days })\end{array}$ & $\begin{array}{l}11.5 \\
15.6 \text { (4 days) }\end{array}$ & ${ }_{6.2}^{0.24}$ (5 days) \\
\hline $\begin{array}{l}\text { Total excess urobil., } m g \\
\text { Conversion to urobil., } \%\end{array}$ & $\begin{array}{r}281.0 \\
95.6\end{array}$ & $\begin{array}{l}16.5 \\
33.0\end{array}$ & $\begin{array}{l}29.8 \\
16.4\end{array}$ \\
\hline \multicolumn{4}{|l|}{ Mesobilifuscin, $m g / d a y$} \\
\hline $\begin{array}{l}\text { Average pre- and post-B-G } \\
\text { Carmine-marked samples }\end{array}$ & $\begin{array}{l}9.0 \\
25.3 \text { (2 days) }\end{array}$ & $\begin{array}{l}0.0 \\
0.0 \text { (4 days) }\end{array}$ & $\begin{array}{l}0.0 \\
0.8 \text { (5 days) }\end{array}$ \\
\hline $\begin{array}{l}\text { Total excess } \mathrm{Mbf}, m g \\
\text { Conversion to } \mathrm{Mbf}, \%\end{array}$ & $\begin{array}{l}32.6 \\
11.1\end{array}$ & $\begin{array}{l}0.0 \\
0.0\end{array}$ & $\begin{array}{l}4.0 \\
2.2\end{array}$ \\
\hline \multicolumn{4}{|l|}{ Bilirubin, $m g / d a y$} \\
\hline $\begin{array}{l}\text { Average pre- and post-B-G } \\
\text { Carmine-marked samples }\end{array}$ & $\begin{array}{r}10.9 \\
1.8 \text { ( } 2 \text { days })\end{array}$ & $\begin{array}{l}0.0 \\
5.5 \text { (4 days) }\end{array}$ & $\begin{array}{l}2.4 \\
0.0 \text { (5 days) }\end{array}$ \\
\hline $\begin{array}{l}\text { Total excess bilirubin, } m g \\
\text { Recovered as bilirubin, \% }\end{array}$ & $\begin{array}{l}0.0 \\
0.0\end{array}$ & $\begin{array}{l}22.5 \\
45.0\end{array}$ & $\begin{array}{l}0.0 \\
0.0\end{array}$ \\
\hline Total recovery, $m g$ & $313,106.7 \%$ & $39.0,78 \%$ & $33.8,18.6 \%$ \\
\hline
\end{tabular}

In Subject 7, given bilirubin in 2 per cent crude bile salt solution, the conversion appeared to be enhanced, with 16.9 per cent recovered as urobilinogen. However, conversion to urobilinogen was not enhanced in the normal subject (no. 5), although bile salts were presumed to be normally present in his duodenum. In three of five subjects $(5,6$, and 7$)$ a very small fraction, less than 1 per cent, was recovered as labeled $\mathrm{Mbf}$; in the other two, no labeled Mbf could be demonstrated. In a single subject (no. 4) a small amount, 0.38 per cent, of the $\mathrm{N}^{15}$-bilirubin appeared in the urine, reflecting a small amount of absorption.

Demonstration of conversion to urobilinogen of the bilirubin native to human bile was more easily provided, as shown in Table II. In this study 19.7 per cent of the administered bilirubin was recovered as excess urobilinogen in the carminemarked feces, 0.6 as $\mathrm{Mbf}$ and 6.6 per cent as bilirubin.

The best recovery of tube-fed bilirubin, as urobilinogen, was noted when bilirubin glucuronide was given (Table III). In a normal subject there was 106 per cent recovery, of which 95.6 per cent was recovered as urobilinogen and the remainder as Mbf. Recovery of bilirubin glucuronide in two patients with biliary obstruction was 78 and 18.6 per cent, respectively. In the former there was 33 per cent conversion to urobilinogen, 45 per cent recovery as bilirubin, and no Mbf formation, while in the latter 16.4 per cent was converted to urobilinogen, 2.2 per cent to $\mathrm{Mbf}$, and none recovered as bilirubin.

When crystalline bilirubin was given intravenously to a normal subject, thus requiring excretion in the bile, it was largely accounted for in the feces as urobilinogen (Table IV). Immediately after starting the daily infusion there was a sharp increase in the daily excretion of urobilinogen and bilirubin and a slight increase in Mbf. During the infusion period there was a total of $850 \mathrm{mg}$ of the three pigments in excess of the pre-

TABLE IV

Administration of $1,082 \mathrm{mg}$ bilirubin i.v. over 8 days to normal adult woman

\begin{tabular}{|c|c|c|c|c|}
\hline $\begin{array}{l}\text { Day of } \\
\text { study }\end{array}$ & Bilirubin & $\begin{array}{l}\text { Av. fecal } \\
\text { urobil. }\end{array}$ & $\begin{array}{c}\text { Av. fecal } \\
\text { Mbf }\end{array}$ & $\begin{array}{l}\text { Av. fecal } \\
\text { bilirubin }\end{array}$ \\
\hline & $m g$ & $m g / d a y$ & $m g / d a y$ & $m g / d a y$ \\
\hline $\begin{array}{c}1-3 \\
4\end{array}$ & & 74.0 & 6.0 & 10.5 \\
\hline $\begin{array}{l}5 \\
6 \\
7 \\
8\end{array}$ & $\left.\begin{array}{r}85 \\
114 \\
142\end{array}\right\}$ & 137.5 & 9.2 & 22.0 \\
\hline & & 219.0 & 14.0 & 39.5 \\
\hline $\begin{array}{c}11 \\
18-21\end{array}$ & $\begin{array}{c}171 \\
0\end{array}$ & 118.0 & 8.3 & 11.7 \\
\hline $\begin{array}{l}\text { Total excess } \\
\text { during period of } \\
\text { infusions }\end{array}$ & 1,082 & 656 & 37.2 & 157.2 \\
\hline \multirow{2}{*}{$\begin{array}{l}\text { Administered bi- } \\
\text { lirubin, \% }\end{array}$} & & 60.6 & 3.5 & 14.5 \\
\hline & \multicolumn{3}{|c|}{ Total recovery $78.6 \%$} & \\
\hline
\end{tabular}


and postinfusion control periods (78.6 per cent of the administered bilirubin). A 60.6 per cent conversion to urobilinogen was measured; 14.5 per cent was recovered as bilirubin and 3.5 per cent was accounted for as Mbf.

These results indicate that conversion of conjugated bilirubin to urobilinogen is much more efficient than is that of free bilirubin. Because of these findings, the patient with refractory anemia and the large discrepancy between the rate of hemoglobin destruction and urobilinogen excretion was suspected of having a defect in the conjugation of bilirubin. This hypothesis received some support from the results obtained after giving her crystalline bilirubin intravenously (Table V). In

TABLE V

Administration of $1,056 \mathrm{mg}$ bilirubin i.v. over 8 days in a case of refractory anemia

\begin{tabular}{|c|c|c|c|c|}
\hline $\begin{array}{l}\text { Day of } \\
\text { study }\end{array}$ & Bilirubin & $\begin{array}{l}\text { Av. fecal } \\
\text { urobil. }\end{array}$ & $\begin{array}{c}\text { Av. fecal } \\
\text { Mbf }\end{array}$ & $\begin{array}{l}\text { Av. fecal } \\
\text { bilirubin }\end{array}$ \\
\hline & $m g$ & $m g / d a y$ & $m g / d a y$ & $m g / d a y$ \\
\hline $\begin{array}{c}1-4 \\
5\end{array}$ & & 30.0 & 6.5 & 7.8 \\
\hline $\begin{array}{l}6 \\
7 \\
8 \\
9\end{array}$ & $\left.\begin{array}{r}83 \\
111 \\
139 \\
167\end{array}\right\}$ & 38.0 & 5.0 & 12.0 \\
\hline $\begin{array}{l}10 \\
11 \\
12\end{array}$ & $\left.\begin{array}{l}167 \\
167 \\
167\end{array}\right\}$ & 22.0 & 14.0 & 10.2 \\
\hline $\begin{array}{l}13-14 \\
15-18\end{array}$ & $\begin{array}{l}\mathbf{0} \\
\mathbf{0}\end{array}$ & $\begin{array}{r}9.0 \\
17.7\end{array}$ & $\begin{array}{l}7.3 \\
2.1\end{array}$ & $\begin{array}{l}7.1 \\
4.9\end{array}$ \\
\hline $\begin{array}{l}\text { Total excess } \\
\text { during period of } \\
\text { infusions }\end{array}$ & 1,056 & 19.0 & 48.0 & 36.0 \\
\hline $\begin{array}{l}\text { Administered bi- } \\
\text { lirubin, } \%\end{array}$ & & 1.7 & 4.5 & 3.4 \\
\hline \multicolumn{5}{|c|}{ Total recovery $9.6 \%$} \\
\hline
\end{tabular}

contrast to the similar study in a normal subject, only a slight increase over the pre- and postinfusion control level was noted in the excretion of urobilinogen, Mbf, and bilirubin during the infusion period in this patient. The total increase in the three fecal pigments was but 9.6 per cent, and there was only 1.7 per cent conversion to urobilinogen. However, when bilirubin glucuronide was administered by duodenal intubation, no increase in any of the three fecal pigments could be demonstrated in the carmine-marked specimens (Table VI). It was then thought that in this patient conjugated bilirubin might have become hydrolyzed in the intestine with formation of free bilirubin. Analyses of multiple samples aspirated from the length of the jejunum are shown in Table VII. It is apparent that the patient excreted conjugated
TABLE VI

Administration of $198 \mathrm{mg}$ bilirubin glucuronide $(B-G)$ by duodenal intubation in a case of chronic refractory anemia *

\begin{tabular}{lccc}
\hline \hline & $\begin{array}{c}\text { Fecal } \\
\text { urobil. }\end{array}$ & $\begin{array}{c}\text { Fecal } \\
\text { Mbf }\end{array}$ & $\begin{array}{c}\text { Fecal } \\
\text { bilirubin }\end{array}$ \\
\hline $\begin{array}{c}\text { Average per diem excretion } \\
\text { pre-B-G, } m g\end{array}$ & 30.0 & 6.5 & 5.4 \\
$\begin{array}{c}\text { Average per diem excretion } \\
\text { carmine-marked specimens } \\
\text { over 3-day period, } m g\end{array}$ & 34.0 & 2.2 & 10.8 \\
$\begin{array}{c}\text { Average per diem excretion } \\
\text { post-B-G, } m g\end{array}$ & 34.8 & 5.2 & 7.0 \\
\hline
\end{tabular}

* Conclusion : No demonstrable recovery of fed bilirubin glucuronide.

bilirubin in the bile and that it remained conjugated throughout the jejunum. This assumes that the 1-minute prompt direct-reacting bilirubin is conjugated. In each sample in Table VII the quantity of direct-reacting bilirubin exceeds the measured quantity of total bilirubin. In our experience this is usually true in measurement of bile bilirubin and is believed to be owing to the fact that both the conjugated, direct-reacting, and the total bilirubins are quantitated on the same curve as that for crystalline bilirubin. This implies a slightly greater absorbance for conjugated bilirubin. Until this substance can be crystallized the question cannot be clarified.

The decreasing amounts of bilirubin in the descending jejunal aspirates are probably best explained on the basis of continuing dilution by intestinal juices. Absorption is also a distinct possibility and will be discussed further. Reduction of bilirubin to urobilinogen cannot be excluded, since the Ehrlich reaction was not applied to these

TABLE VII

\begin{tabular}{|c|c|c|}
\hline Specimen & $\begin{array}{c}\text { Prompt } \\
\text { direct- } \\
\text { reacting } \\
\text { (1-min) } \\
\text { bilirubin }\end{array}$ & $\begin{array}{c}\text { Total } \\
\text { bilirubin }\end{array}$ \\
\hline & $m g \%$ & $m g \%$ \\
\hline 1 & 3.75 & 3.50 \\
\hline 2 & 3.05 & 2.50 \\
\hline 3 & 2.45 & 1.90 \\
\hline 4 & 1.75 & 1.45 \\
\hline 5 & 1.93 & 1.40 \\
\hline 6 & 0.58 & 0.35 \\
\hline 7 & 0.30 & 0.26 \\
\hline 8 & 0.45 & 0.36 \\
\hline 9 & 0.64 & 0.52 \\
\hline
\end{tabular}


TABLE VIII

\begin{tabular}{|c|c|c|c|}
\hline & $\begin{array}{l}\text { Fecal } \\
\text { urobil. } \\
\text { group* }\end{array}$ & $\begin{array}{l}\text { Fecal } \\
\mathrm{Mbf}\end{array}$ & $\begin{array}{c}\text { Fecal } \\
\text { bilirubin }\end{array}$ \\
\hline $\begin{array}{l}\text { Average per diem excretion, } \\
m g\end{array}$ & 15.5 & 1.6 & 9.4 \\
\hline $\begin{array}{l}\text { Average per diem excretion } \\
\text { in carmine-marked samples } \\
\text { in 3-day period after i-U } \\
\text { administration, } m g\end{array}$ & 75.6 & 6.0 & 6.0 \\
\hline $\begin{array}{l}\text { Total excess in carmine- } \\
\text { marked samples in 3-day } \\
\text { period, } m g\end{array}$ & 180.0 & 13.2 & 0.0 \\
\hline Recovery of administered & 122.0 & 8.9 & 0.0 \\
\hline \multicolumn{4}{|c|}{$1-0, \% \quad$ Total recovery $193.2 \mathrm{mg}$ or $\mathbf{1 3 0 . 9} \%$} \\
\hline
\end{tabular}

* See text.

specimens. On the basis of our previous experience with small bowel contents this appears unlikely. In view of the previously noted discrepancies between bilirubin and urobilinogen excretion in this patient, it is possible that conversion of bilirubin to other unrecognized pigments occurred. To exclude the possibility that there was abnormal destruction of urobilinogen in, or excessive absorption of urobilinogen from, the intestine, crystalline mesobilirubinogen, or i-urobilinogen, was administered by duodenal tube (Table VIII); complete recovery of the fed mesobilirubinogen is seen. It is of interest that, of the $227 \mathrm{mg}$ of the total urobilinogen group in the carmine-marked samples, 69 per cent was $l$-stercobilinogen (3). In an earlier control period, 90 per cent of the total was $l$-stercobilinogen, while the small amount obtained from the urine for 41 hours after administration of the mesobilirubinogen (i-urobilinogen) contained but 44 per cent of $l$-stercobilinogen. These figures are in accord with expectation if one assumes that a minor fraction of the $\mathrm{i}$-urobilinogen was absorbed unchanged and excreted in the urine ; and another significant fraction was converted to $l$-stercobilinogen in the colon, of which a small part was absorbed and excreted in the urine, the remainder being found in the feces.

\section{DISCUSSION}

Evidence obtained from studies with $\mathrm{N}^{15}$-glycine, and a survey of a large number of patients with a variety of hematologic and hepatic disorders, has indicated that the dipyrrylmethene pigments such as mesobilifuscin are mainly anabolic in character, relating to heme synthesis rather than to hemoglobin destruction as formerly assumed $(14,15)$. The idea that inability to recover significant quantities of tube-fed crystalline bilirubin as urobilinogen, or that discrepancies between the rate of hemoglobin breakdown and urobilinogen excretion might be reconciled by the measurement of Mbf, has been dispelled by the present studies. These show clearly that only small amounts of Mbf were derived from bilirubin administered intraduodenally or intravenously. In fact, in two subjects receiving crystalline $\mathrm{N}^{15}$ bilirubin and one receiving bilirubin glucuronide by duodenal tube, no conversion to Mbf could be demonstrated. In all other subjects the measured conversion to Mbf was but a small fraction of the conversion to urobilinogen and, in most cases, this fraction was much smaller than was represented by native Mbf in the feces. Nevertheless, it is evident that significant increases of Mbf were at times observed after administration of either bilirubin (Tables III, IV, and V) or mesobilirubinogen (Table VIII). Whether this is owing to the rapid increment in concentration of these substances in the intestine, or to the relatively artificial manner of their addition (probably not applicable in the case of the intravenously administered bilirubin), or to other factors, is unknown. In so far as the first possibility is concerned, the present observations do raise the question as to what proportion of the increased fecal Mbf in hemolytic states is derived from schism of bilirubinoid rather than from anabolic sources. Our previous studies with $\mathrm{N}^{15}$-glycine in the normal state support the latter mode of origin but it is quite possible that, with rapid increments of bilirubinoid in the intestine, schism might well become of greater significance in mesobilifuscin formation.

It is important to note that the method employed for determination of $\mathrm{Mbf}$ in feces and urine excludes any artifactual contribution of bilirubin or biliverdin, as well as of urobilinogen, the first two substances being adsorbed on the initial ferrous hydroxide, the urobilinogen being extracted from the acidified filtrate. Biliverdin glucuronide obtained from human bile (19), when subjected directly to the method for Mbf determination without ferrous hydroxide treatment at the outset, yields a final solution of dark green color which would interefere with the determination of $\mathrm{Mbf}$. 
It is quite clear that the quantity of fecal Mbf was inconsequential in explaining the discrepancy between hemoglobin destruction and fecal urobilinogen in the patient with refractory anemia. This has also been evident in other subjects in whom lesser discrepancies were encountered.

The conjugation of bilirubin appears to be of much greater significance in the failure to demonstrate conversion of tube-fed crystalline bilirubin, at least in normal individuals (see above). When bile, which normally contains conjugated bilirubin, or a crude preparation of bilirubin glucuronide was administered, the measured conversion to urobilinogen was substantially enhanced. In like manner, when crystalline bilirubin was given intravenously to a normal individual so that conjugation by the liver could take place, an abundant increase in fecal urobilinogen was observed. These data indicate that reduction of conjugated bilirubin by the fecal bacteria proceeds much more efficiently than that of free bilirubin, in accord with previous in vitro studies. It seems not unlikely, however, that when bile is excluded from the intestine, bacterial activity is not optimal for conversion of bilirubin to urobilinogen even when the former is conjugated. It is seen in Table III that only 16 to 33 per cent of the administered bilirubin was represented as urobilinogen in the feces, in contrast to 95 per cent in the normal control. It is not clear whether bile acids are of direct significance, although this may be suggested by the fact that in Subject 7 (Table I) 16.9 per cent conversion was noted, and here crystalline bilirubin was administered with a relatively large amount of bile salts. An alternative explanation is that the bile salts partially interfered with absorption of free bilirubin (see below) simply by competition for the mucosal surface. The crude conjugate given to the two subjects with biliary obstruction (Table III) included much smaller, probably insignificant, amounts of bile acids (see above).

The possibility that free bilirubin is absorbed from the gastrointestinal tract to be conjugated by the liver and re-excreted in the bile was not examined in the present studies. In retrospect, it would have been interesting to run $\mathrm{N}^{15}$ analyses on the fecal stercobilin which followed the carmine-labeled samples in Subjects 5 and 6 in Table I. If there were enterohepatic circulation of bili- rubin this would not be evident until a later period. Since completion of the present experiments, Lester, Ostrow and Schmid (31) have demonstrated an enterohepatic circulation of bilirubin in the rat. Stimulated by these observations, we have recently administered $\mathrm{N}^{15}$-bilirubin via duodenal tube in a patient with a $\mathrm{T}$-tube in the common duct. Serial isolation of crystalline bilirubin, thereafter, clearly demonstrated an enterohepatic circulation. The details of this experiment will be described separately. It is quite possible that absorption of bilirubin is in some way responsible for the disappearance of large fractions of tube-fed sodium bilirubinate.

Although it is probable that a defect in conjugation of bilirubin would result in diminished fecal urobilinogen, it is also clear that in certain pathologic states there are other unknown, but highly significant, factors causing deviation from the normal pathway of bilirubin reduction. The discrepancy between fecal urobilinogen and hemoglobin destruction was striking in our patient with refractory anemia. Yet, the bilirubin throughout the length of the jejunum was found to be entirely polar in behavior (prompt direct 1-minute diazo reaction), and no significant conversion to urobilinogen was demonstrated from tube-fed bilirubin glucuronide, in contrast to the normal control subject. The progressively diminishing concentration through the small bowel may have been owing to dilution or to absorption of the conjugated bilirubin. Occurrence of the latter in man has not yet been demonstrated. It is conceivable that, as conjugated bilirubin passes down the small intestine, it is hydrolyzed at a variable rate, and the fraction of free bilirubin thus formed is then absorbed. In such an abnormal case as Patient A.B., most of the conjugate might have been hydrolyzed before reaching the cecum. Some alteration of bilirubin in the liver or elsewhere would also have to be postulated to explain the striking contrast between the results in this case and those in the normal controls. Excessive absorption or other defects in handling of urobilinogen by the intestine appeared to be excluded in this case, since tube-fed mesobilirubinogen was completely recovered, being partially converted to $l$-stercobilinogen in transit. The discrepancy in this patient remains unexplained; also the question of its relationship, if any, to the idiopathic 
refractory anemia (see below). It is possible that bilirubin is converted in the intestine to some other material as yet unrecognized. The presence of an abnormal bacterial flora in the intestine might conceivably promote the formation from bilirubin of a compound or compounds other than urobilinogen, undetected by current methods.

Finally, it is interesting to speculate upon a possible relationship between the abnormal pigment metabolism in this patient and the clinically refractory anemia. The suggestion has been made in the past that bilirubin $(32,33)$, stercobilin (10), or chlorophyll (34) might stimulate erythropoiesis. None of these possibilities has been proven or disproven, and further studies are clearly needed. There is also a possibility that in certain pathologic states, as in Patient A.B., formation of abnormal bilirubin derivatives might suppress hemoglobin formation and erythropoiesis.

\section{SUMMARY AND CONCLUSIONS}

1. A comparative study was made of the recovery of urobilinogen, bilirubin, and mesobilifuscin in the feces of human subjects who had been fed by tube with solutions of crystalline $\mathrm{N}^{15}$ bilirubin as the sodium salt, bile, and crude concentrates of bilirubin glucuronide; and after intravenous administration of crystalline bilirubin in $0.1 \mathrm{M} \mathrm{Na}_{2} \mathrm{CO}_{3}$ solution.

2. Mesobilifuscin was not a significant conversion product of bilirubin. Measurement of mesobilifuscin did not reconcile discrepancies between hemoglobin destruction and urobilinogen excretion, nor did it account for the failure to demonstrate conversion of tube-fed bilirubin to urobilinogen.

3 . In contrast to free bilirubin, conjugated bilirubin from human bile was much more readily accounted for by the amount of fecal urobilinogen. Crystalline bilirubin given intravenously in $0.1 \mathrm{M}$ $\mathrm{Na}_{2} \mathrm{CO}_{3}$ solution was apparently conjugated in the liver and was largely recovered as fecal urobilinogen.

4. A case of refractory anemia is described in which an abnormal pathway of bilirubin metabolism was demonstrated. In this instance, in contrast to the normal control observations, tube-fed bilirubin glucuronide or intravenously administered crystalline bilirubin was largely unaccounted for as urobilinogen, mesobilifuscin, or bilirubin, in the excreta. In the same individual no evidence could be obtained of faulty conjugation of bilirubin or hydrolysis of the conjugate in the small intestine, nor was there any failure to account for tube-fed mesobilirubinogen (i-urobilinogen). The possibility is considered that there was abnormal reabsorption of bilirubin.

\section{REFERENCES}

1. Watson, C. J. The pyrrol pigments and hemoglobin catabolism (E. T. Bell Lecture). Minn. Med. 1956, 39, 294, 403, 467.

2. Watson, C. J. Some challenging aspects of hemoglobin metabolism. (John Philips Lecture) Ann. intern. Med. 1957, 47, 611.

3. Watson, C. J. and Weimer, M. Composition of the urobilin group in urine, bile, and feces and the significance of variations in health and disease. $\mathrm{J}$. Lab. clin. Med. 1959, 54, 1.

4. Maly, R. Künstliche Umwandlung von Bilirubin in Harnfarbstoff. Justus Liebigs Ann. Chem. 1872, 161, 368.

5. Maly, R. Untersuchungen über die Gallenfarbstoffe Dritte Abh. Umwandlung von Bilirubin in Harnfarbstoff. Justus Liebigs Ann. Chem. 1872, 163, 77.

6. von Müller, F. Über Icterus. Jber. Schlesische Gesellschaff f. vaterl. Kultur. 1893, 70, 1.

7. Fromholdt, G., and Nersessoff, N. Beiträge zur Urobilinfrage (III). Z. exp. Path. Ther. 1912, 11, 400.

8. Walzel, P., and Weltmann, O. Studien zur Gallensekretion bei einer Leber-Gallenfistel nach vorausgegangener Totalexstirpation einer sogen idiopathischen Choledochuscyste. Mitt. Grenzgeb. Med. Chir. 1924, 37, 437.

9. Fischer, H., and Libowitzky, H. Zur Kenntnis des Stercobilins. Hoppe-Seylers Z. physiol. Chem. 1939, 258, 255.

10. Watson, C. J. The pyrrol pigments, with particular reference to normal and pathologic hemoglobin metabolism in Handbook of Hematology, $\mathrm{H}$. Downey, Ed. New York, Hoeber, 1938, vol. 4, p. 2447.

11. Siedel, W., and Möller, H. Utber Mesobilifuscin, ein neues physiologisches Abbauprodukt des Häms bzw. Hämatins. I. Konstitution und Teilsynthese. Hoppe-Seylers Z. physiol. Chem. 1939, 259, 113.

12. Siedel, W., Stich, W., and Eisenreich, F. Promesobilifuscin (Meso-bilileukan), ein neues physiologisches Abbauprodukt des Blutfarbstoffes. Naturwissenschaften 1948, 35, 316.

13. Netousek, M. Uber den Abbau des Blutfarbstoffes. Acta med. Acad. Sci. hung. 1956, 9, 143.

14. Gilbertsen, A. S., Lowry, P. T., Hawkinson, V., and Watson, C. J. Studies of the dipyrrylmethene 
("fuscin") pigments. I. The anabolic significance of the fecal mesobilifuscin. J. clin. Invest. 1959, 38, 1166.

15. Gilbertsen, A. S., Hawkinson, V., and Watson, C. J. Studies of the dipyrrylmethene ("fuscin") pigments. II. The contrasting ratios and significance of the fecal urobilinogen and mesobilifuscin in certain anemias. J. clin. Invest. 1959, 38, 1175.

16. Billing, B. H., and Lathe, G. H. The excretion of bilirubin as an ester glucuronide, giving the direct Van den Bergh reaction. Biochem. J. 1956, 63, $6 \mathrm{P}$.

17. Schmid, R. Direct-reacting bilirubin, bilirubin glucuronide, in serum, bile, and urine. Science 1956, 124, 76.

18. Schmid, R., Hammaker, L., and Axelrod, J. The enzymatic formation of bilirubin glucuronide. Arch. Biochem. 1957, 70, 285.

19. Watson, C. J., Campbell, M., and Lowry, P. T. Preferential reduction of conjugated bilirubin to urobilinogen by normal fecal flora. Proc. Soc. exp. Biol. (N. Y.) 1958, 98, 707.

20. Baumgärtel, $T$. Über die Inaktivierung von Fermenten durch Bilirubin; experimenteller Beitrag zur Genese des Urobilinogens. Med. Klin. 1958, 53, 1331.

21. Lowry, P. T., Bossenmaier, I., and Watson, C. J. A method for the isolation of bilirubin from feces. J. biol. Chem. 1953, 202, 305.

22. Carey, J. B., Jr. The serum trihydroxy-dihydroxy bile acid ratio in liver and biliary tract disease. J. clin. Invest. 1958, 37, 1494.

23. Schwartz, S., Sborov, V., and Watson, C. J. Studies of urobilinogen. IV. The quantitative determination of urobilinogen by means of the Evelyn photoelectric colorimeter. Amer. J. clin. Path. 1944, 14, 598.

24. Malloy, H. T., and Evelyn, K. A. Oxidation method for bilirubin determinations in bile and meconium with photoelectric colorimeter. J. biol. Chem. 1938, 122, 597.

25. Watson, C. J., Lowry, P. T., Sborov, V. E., Hollinshead, W. H., Kohan, S., and Matte, H. O. A simple method of isolation of crystalline stercobilin or urobilin from feces. J. biol. Chem. 1953, 200, 697.

26. Rittenberg, D. Preparation of gas samples for massspectrographic isotope analysis in Preparation and Measurement of Isotope Tracers: A Symposium. Ann Arbor, Mich., Edwards, 1948, p. 31.

27. Read, R. C. Studies of red-cell volume and turnover using radiochromium. Description of a new "closed" method of red-cell-volume measurement. New Engl. J. Med. 1954, 250, 1021.

28. Fischer, H., and Orth, H. Die Chemie des Pyrrols. Leipzig, Akad. Verlagsgesellsch., 1937, vol. II.

29. Ducci, H., and Watson, C. J. The quantitative determination of the serum bilirubin with special reference to the prompt-reacting and the chloroform-soluble types. J. Lab. clin. Med. 1945, 30, 293.

30. Zieve, L., Hill, E., Hanson, M., Falcone, A. B., and Watson, C. J. Normal and abnormal variations and clinical significance of the one-minute and total. serum bilirubin determinations. J. Lab. clin. Med. 1951, 38, 446.

31. Lester, R., Ostrow, J. D., and Schmid, R. Enterohepatic circulation of bilirubin. Nature (Lond.) 1961, 192, 372.

32. Zih, A. Utber den Einfluss des Bilirubins auf die Regeneration bei Aderlassanämien. Z. ges. exp. Med. 1939, 106, 132.

33. Zih, A. Uber die erythropoietische Wirkung des Bilirubins bei anämischen Menschen. Z ges. exp. Med. 1939, 106, 136.

34. Patek, A. J. Chlorophyll and regeneration of the blood. Effect of administration of chlorophyll derivatives to patients with chronic hypochromic anemia. Arch. intern. Med. 1936, 57, 73. 